\title{
WEATHER AND PREDATION PRESSURE: THE CASE OF THE RED-BACKED SHRIKE (LANIUS COLLURIO)
}

\author{
Artur Golawski ${ }^{1}$ and Sylwia Golawska ${ }^{2}$ \\ ${ }^{1}$ Siedlce University of Natural Sciences and Humanities, Faculty of Natural Science \\ Department of Zoology, Prusa 14, 08-110 Siedlce, Poland \\ E-mail: artur.golawski@uph.edu.pl; https://orcid.org/0000-0001-9806-2119 \\ ${ }^{2}$ Siedlce University of Natural Sciences and Humanities, Faculty of Natural Science \\ Department of Biochemistry and Molecular Biology, Prusa 14, 08-110 Siedlce, Poland \\ E-mail: sylwia.golawska@uph.edu.pl; https://orcid.org/0000-0001-9192-6738
}

Breeding success in birds is seriously affected by predation, although behaviourist extent can be modified by the weather, its mechanisms are not well understood. Analysis of the breeding success of Red-backed Shrikes (Lanius collurio) in eastern Poland, which has a temperate transitional climate, showed that predation did indeed increase significantly during periods of prolonged rainfall, but that air temperature and wind speed did not affect predation significantly. As insects become less active during rainy weather, predators like Magpies (Pica pica) and Jays (Garrulus glandarius), which frequently consume such prey, then have to switch to birds' eggs and nestlings as sources of food. In recent years, less rain has been falling in this part of Poland in the summer, so one can anticipate a higher level of breeding success in the Red-backed Shrike, if the numbers of potential predators do not increase equally quickly.

Keywords: corvids, nest survival, Poland, population ecology, rainfall, Lanius collurio

\section{INTRODUCTION}

As nesting success is one of the most important demographic parameters influencing population viability, it has probably been documented more extensively than any other facet of avian breeding ecology (MARTIN 1995, Donovan \& Thompson 2001). Numerous studies have focused on the importance of single and multiple ecological or social factors for reproductive performance (Newton 1998), e.g. weather conditions, which can severely impact reproductive performance (Rodriguez \& Bustamante 2003). Even when a whole range of factors is analysed, weather conditions are usually interpreted as having directly affected the breeding success (Muller et al. 2005); this is because the weather can strongly influence foraging conditions and lead to the chilling or starvation of young birds (NEWTON 1998). Sometimes, extreme climatic events (e.g., hurricanes and droughts) can result in complete reproductive failure of birds (Moreno \& Møller 2011).

Weather affects not only the foraging conditions and metabolic rate of birds; it can also have indirect effects on bird behaviour (CRICK 2004). Predators and weather interact to influence nesting success, but the mechanisms are 
not well understood (Morrison \& Bolger 2002, Sherry et al. 2015); indeed, they are barely mentioned in the literature. Recent papers have not revealed any clear dependence between rates of nest predation and air temperature (Cox et al. 2013, SHerry et al. 2015); the effects of other meteorological factors like rainfall and wind are even less well known (Collister \& Wilson 2007, Bionda \& BRAMBILLA 2012).

The present work analyses the effect of weather factors (temperature, rainfall, wind speed) on the level of predation on clutches/broods of the Redbacked Shrike (Lanius collurio Linnaeus, 1758). We focused only on the direct influence of weather on the level of predation. Therefore, we do not consider the influence of weather on vegetation growth, which may mask the nests, and (Howlett \& Stutchbury 1996) showed that better hidden nests had higher breeding success. Understanding how weather influences predation pressure is crucial if we are to accurately forecast how continued climate change will affect the viability of bird populations. Predation is the most frequent cause of nest loss in Red-backed Shrike across its distribution (HARris \& FrankLIN 2000), as well as other songbirds (RICKLEFs 1969, MARTIN 1995).

\section{MATERIAL AND METHODS}

\section{Study species}

The Red-backed Shrike is a small passerine bird species widely distributed in Europe and Western Asia with population estimates ranging from 24 to 48 million breeding pairs (BirdLife International 2019). It is a long distance migrant, which arrives its breeding grounds from Africa in early May (HARRIs \& FrANKLIN 2000). In eastern Poland, the majority of the population inhabits agricultural landscapes, breeding on the edge of woods, in tree clusters, orchards and in the vicinity of villages (Golawski \& Meissner 2008). The nest is an open cup, 100-190 $\mathrm{mm}$ in diameter and $50-110 \mathrm{~mm}$ tall, made mainly from grass and usually placed at heights of ca. $1.3 \mathrm{~m}$ in various parts of bushes or trees (HARRIS \& FrANKLIN 2000). The breeding season usually starts in the middle of May and goes through to August. Four to seven eggs are laid and incubated for 14 days. The nestlings remain in the nest for the next 14 days (HARris \& FrankLIN 2000). This species is normally single-brooded, but in the case of first brood failure, replacement clutches are laid regularly (ANTCZAK et al. 2009). The Redbacked Shrike is a mainly insectivorous species (TRYJANOWSKI et al. 2003, GolawsKi 2006a).

\section{Bird data}

The study was carried out between 1999-2003 and 2012-2018 in eastern Poland, near Siedlce $\left(52^{\circ} 12^{\prime} \mathrm{N}, 22^{\circ} 17^{\prime} \mathrm{E}\right)$, which has a temperate transitional climate (DeGIRMENDZIC et al. 2004). The 300 ha study area covered a landscape of extensive agriculture, with habitats such as pastures, meadows, cultivated and uncultivated fields, small forest patches, scrub and small urban areas (Golawski \& Meissner 2008). Red-backed Shrike nests were searched for and subsequently inspected between mid-May and early August. Its breeding 
success in this part of the country is ca. $50 \%$, and the main predators of its clutches/broods are corvids, especially Magpies (Pica pica Linnaeus, 1758) and Jays (Garrulus glandarius Linnaeus, 1758) (Golawski \& Mitrus 2014). This analysis included only those clutches that were found during the egg-laying period or the few first days of incubation. A total of 393 nests were found, but only 237 of them are analysed here. Clutches lost as a result of factors other than predation (e.g. nests destroyed by agricultural activities, desertion) were ignored. Nests were considered successful if at least one nestling had fledged. Because Red-backed Shrikes are sensitive to nest disturbance (TrYJAnOwsKi \& KuZNiaK 1999), the nest control lasted a few seconds and was carried out very carefully. All nests were controlled with the same intensity in every five days.

The Red-backed Shrike's breeding period was divided into 5-day periods because it was at such time intervals that the nests were usually monitored. Such division has a significant advantage because it is possible to assign a fairly precise period of breeding loss to the weather conditions prevailing during this period. For each period, the number of active nests and the number of clutches/broods lost were calculated; in the subsequent analysis, the percentage of active nests in relation to all nests was used. The meteorological data were measured for these same 5-day periods (mean, maximum and minimum temperatures, wind speed, total rainfall, number of days with rain). Air temperatures and wind speeds are given as average values, while in the case of rainfall, the total amount of rain and the number of days with rain are given for each 5-day period. The weather data were obtained from the website: http://www.tutiempo.net for the nearest meteorological station in Siedlce, the nearest town $10 \mathrm{~km}$ south of the study area. Table 1 shows weather characteristics for five days periods of nesting.

\section{Statistical analysis}

A general linear mixed model (GLMM) was used with Gamma error distribution and $\log$ link function to test the effects of parameters describing weather factors on the percentage survival of clutches in 5-day periods in the red-backed shrike. The presence of multicollinearity was checked for among the six variables by using the variance inflation factor (VIF), where VIF greater than 10 indicates "severe" collinearity (QuinN \& KeOUGH 2002, KutNer et al. 2004). Three factors were excluded from the analysis (maximum and minimum temperatures and total rainfall), because these variables had VIF $>10$, suggesting multicollinearity. In consequence, the GLMM analysis covered the following parameters modelled as fixed continuous variables: (1) mean temperature, (2) number of days

Table 1. Characteristics of weather factors based on 5-day periods during the breeding season of the Red-backed Shrike in eastern Poland; $\mathrm{N}=183$ 5-day periods, 12 years.

\begin{tabular}{lcccc}
\hline Variable & Mean & SE & Min & Max \\
\hline Mean temperature $\left({ }^{\circ} \mathrm{C}\right)$ & 17.9 & 0.21 & 11.2 & 24.5 \\
Maximum temperature $\left({ }^{\circ} \mathrm{C}\right)$ & 23.7 & 0.25 & 15.6 & 30.8 \\
Minimum temperature $\left({ }^{\circ} \mathrm{C}\right)$ & 11.5 & 0.22 & 2.4 & 17.8 \\
Total rainfall $(\mathrm{mm})$ & 11.6 & 1.01 & 0.0 & 89.7 \\
Number of days with rain & 2.3 & 0.11 & 0 & 5 \\
Wind speed $(\mathrm{km} / \mathrm{h})$ & 8.9 & 0.14 & 4.8 & 15.5 \\
\hline
\end{tabular}


with rain, (3) wind speed. The GLMM was used as a full model because it contained only three fixed factors. The interaction between factors in GLMM was introduced in the initial parameterization, but was removed from the model because it was non-significant. Since the air temperature rose distinctly $(R=0.53, P<0.001, N=183)$ as the season progressed (May-August), a variable describing the progress of the season (5-day periods) was added as a random factor in the GLMM analyses. "Year" was another random factor included. The response variable was the percentage of clutches/broods that survived a given 5-day period compared with all the clutches/broods in the same 5-day period. Since all the clutches/broods were monitored from the end of egg laying or the first three days of incubation, Mayfield's method for estimating nest survival when nests are found at different stages of clutch advancement was not used. Only results with a probability of $\alpha \leq 0.05$ were assumed to be statistically significant. Statistics were performed in SPSS version 21.0. for Windows (SPSS INC. 2012).

\section{RESULTS}

Red-backed Shrikes achieved an overall breeding success of $47 \%$ ( $N=237$ clutches); 64 clutches were lost during incubation and 61 at the nestling stage. The percentage of clutches/broods surviving a 5-day period varied from 25 to $100 \%$ ( $N=1835$-day periods during the 12-year study). This percentage was significantly dependent on the number of days with rain during this period (GLMM, $F_{1,179}=9.12, P=0.003$ ): the more days with rain, the more clutches/ broods fell victim to predators (Table 2, Fig. 1A). On the other hand, the percentage of lost clutches/broods did not depend on the mean air temperature (GLMM, $F_{1,179}=2.20, P=0.140$, Fig. $1 \mathrm{~B}$ ) or on the average wind speed in the various 5-day periods (GLMM, $F_{1,179}=0.31, P=0.578$ ). In the case of the latter factors, a trend was discernible whereby the percentage of clutches/broods lost increased with increasing wind speed (Fig. 1C), but it was not significant (Table 2).

\section{DISCUSSION}

The Red-backed Shrike avoids areas with high levels of rainfall, such as sea coasts in the western part of Europe, probably because of the limited ac-

Table 2. Results of the general linear mixed model showing factors affecting the survival of clutches in the Red-backed Shrike. Years and progress of season were used as random effects. The number of observations was 183 .

\begin{tabular}{lcccr}
\hline Effects & Estimate & SE & $t$-value & $P$-value \\
\hline Intercept & 1.094 & 0.082 & 13.352 & $<0.001$ \\
Mean temperature & -0.005 & 0.003 & -1.484 & 0.140 \\
Number of days with rain & -0.018 & 0.006 & -3.021 & 0.003 \\
Wind speed & -0.003 & 0.005 & -0.557 & 0.578 \\
\hline
\end{tabular}




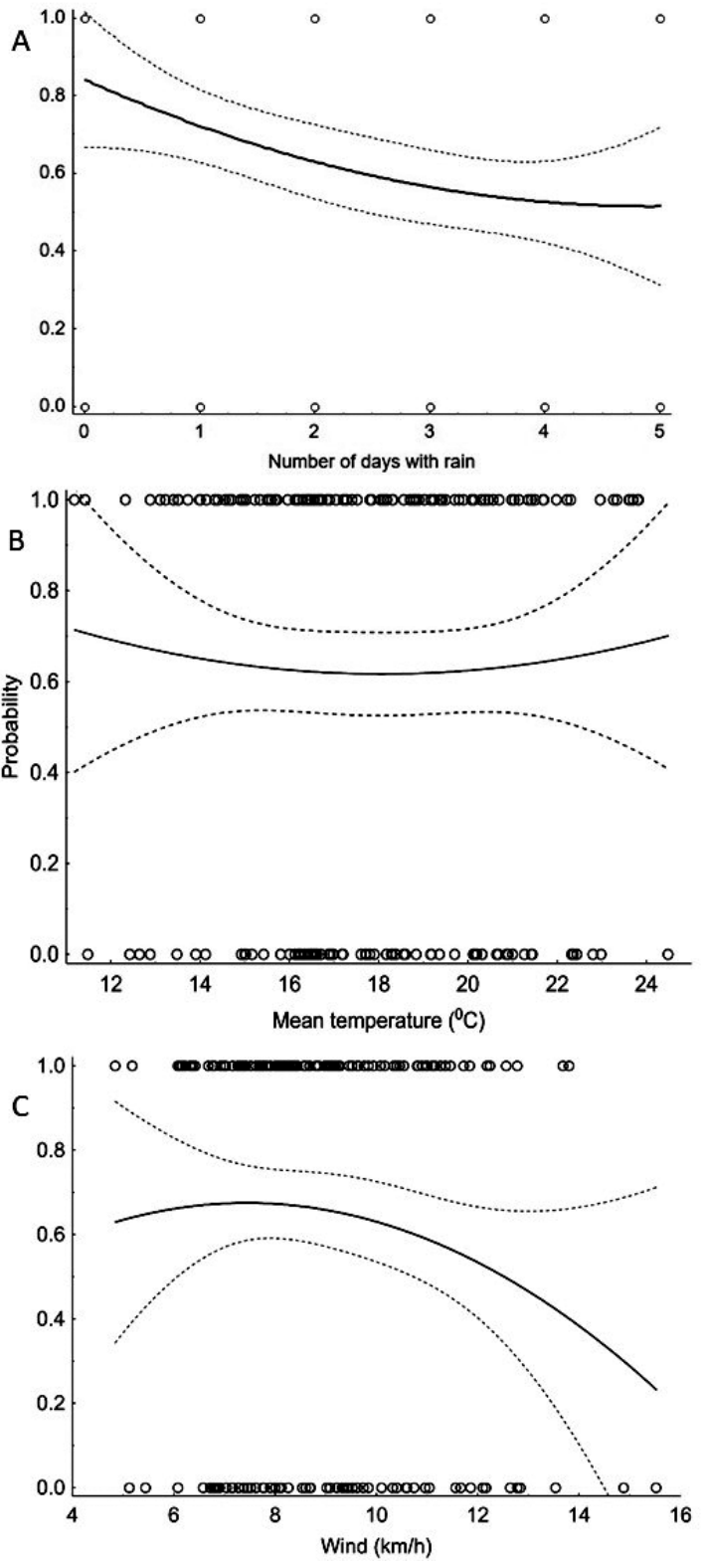

Fig. 1. Predicted probability of weather factors influencing the breeding success of the Red-backed Shrike. The solid lines indicate the predicted probability, the dashed lines correspond to the 95\% confidence interval, and the open circles indicate the observed value ( 1 - breeding success, 0 - failure) cess to appropriate food (HARRIS \& FRANKLIN 2000). In eastern Poland, where the climate is continental-like, inclement weather had just a slight effect on this species' reproduction; only rainfall had an evidently adverse effect (GoLAwsKi 2006b, 2008, Golawski \& Mitrus 2018). Generally speaking, only episodes of extremely poor weather, occurring once every few years, led to greater mortality of shrike clutches/broods (TAKAGI 2001). This study showed that predators destroyed relatively more clutches/broods during prolonged periods of rain (measured as the number of days with rainfall) than in periods when rain fell intermittently. This dependence should be explained by the behaviour of potential predators of Redbacked Shrike nests, i.e. corvids, in response to rainfall. Both Magpies and Jays are omnivores, typically consuming large numbers of invertebrates (e.g. orthopterans, coleopterans, hymenopterans) (JERZAK 2001). The lower temperatures and strong winds during rainy weather cause insects to become less active (Vicens \& Bosch 2000, Yosef \& Pinshow 2005) and fewer are on the wing at such times. Under such circumstances, corvids shift their attention to birds' eggs and nestlings (Schmidt \& WhelaN 
1999, SHERry et al. 2015). The research area was a mosaic of habitats, and crow nests were scattered throughout this area. We found no effect of the distance of shrike nests from corvid nests on clutch predation in shrikes (GolawsKI \& Mitrus 2014). Furthermore, shrikes relatively poorly hide their nests, and in the described area, it was not found that hiding the nest influenced the breeding success of the species (Golawski \& Mitrus 2008). Shrikes are aggressive birds, quite capable of defending their nests from predators (TRYJANOWSKI \& GolawsKi 2004), but inclement weather affects their foraging, too: fewer prey items (mainly insects) are then available to them, so that the parent birds have to spend more time foraging and less time defending the nest (COLLister \& WiLSON 2007). Such extending the foraging time by parents is particularly worth emphasizing because it allows an easy destruction of nests by predators, not only by corvids, but also by mammals like martens or domestic cats (Felis catus Linnaeus, 1758) (Kuzniak \& TryJanowski 2003). Rainfall can thus limit the breeding success of Red-backed Shrikes and contribute to an increase in partial losses as a result of a food deficit during such weather (TRYJANOwSKI et al. 2003, Golawski 2006b, Jørgensen et al. 2013).

\section{CONCLUSIONS}

In the light of climate changes, one can speculate on the future of the Red-backed Shrike population nesting in eastern Poland. Summer rainfall in Poland has decreased slightly in recent years (Degirmendzic et al. 2004), which ought to be beneficial for this shrike's breeding success, and thus for the continued survival of the breeding population. Moreover, the lack of rainfall facilitates the acquisition of food, which is, of course, favorable for shrikes and many other bird species (Takagi 2001, Tryjanowski et al. 2003). Poland lies in the centre of this species' range of distribution. Red-backed Shrike number is gradually rising: at present, there are about 1 million breeding pairs in the country - this is ca $8.5 \%$ of the European population (KuCZYŃsKI \& Chylarecki 2012, Chodкiewicz et al. 2015). Nevertheless, this does not allow one to predict a strong increase in the numbers of these shrikes, because the numbers of Magpies and Jays (the most important predators of Red-backed Shrike nests) are also rising gradually (KuCZYŃsKi \& CHYLARECKI 2012).

Acknowledgements - We would like to thank Emilia Mroz for carrying out the surveys, and we are grateful to Peter Senn for the English language editing. We are also grateful to the anonymous reviewers for their helpful comments. This research was carried out under research theme no. 75/94/s and was financed from a science grant granted by the Ministry of Science and Higher Education. 


\section{REFERENCES}

Antczak, M., Golawski, A., Kuźniak, S. \& Tryjanowski, P. (2009): Costly replacement how do different stages of nest failure affect clutch replacement in the red-backed shrikes Lanius collurio? - Ethology Ecology \& Evolution 21: 127-136. https://doi.org/10 $.1080 / 08927014.2009 .9522501$

Bionda, R. \& BRAmbilla, M. (2012): Rainfall and landscape features affect productivity in an alpine population of Eagle Owl Bubo bubo. - Journal of Ornitology 153: 167-171. https://doi.org/10.1007/s10336-011-0721-2

BirdLife International (2019): Species factsheet: Lanius collurio. Downloaded from http://www.birdlife.org [accessed on 05/04/2019]

Chodkiemicz, T., Kuczyński, L., Sikora, A., Chylarecki, P., Neubauer, G., Ławicki, Ł. \& StawarczyK, T. (2015): Population estimates of breeding birds in Poland in 20082012. - Ornis Polonica 56: 149-189.

Collister, D. M. \& Wilson, S. (2007): Contributions of weather and predation to reduced breeding success in a threatened northern Loggerhead Shrike population. - Avian Conservation and Ecology 2: article 11. https://doi.org/10.5751/ACE-00193-020211

Cox, W., Thompson, III F. R. \& Riedy, J. L. (2013): The effects of temperature on nest predation by mammals, birds and snakes. - Auk 130: 1-7. https://doi.org/10.1525/ auk.2013.13033

CRICK, H. Q. P. (2004): The impact of climate change on birds. - Ibis 146: 48-56. https://doi. org/10.1111/j.1474-919X.2004.00327.x

Degirmendzic, J., Kozuchowski, K. \& Zmudzka, E. (2004): Changes of air temperature and precipitation in Poland in the period 1951-2000 and their relationship to atmospheric circulation. - International Journal of Climatology 24: 291-310. https://doi.org/10.1002/ joc. 1010

Donovan, T. M. \& Thompson, III F. R. (2001): Modeling the ecological trap hypothesis: A habitat and demographic analysis for migrant songbirds. - Ecological Applications 11: 871-882. https://doi.org/10.1890/1051-0761(2001)011[0871:MTETHA]2.0.CO;2

Golawski, A. (2006a): Comparison of methods for diet analysis and prey preference: a case study on the Red-backed Shrike Lanius collurio. - Ornis Fennica 83: 108-116.

Golawski, A. (2006b): Impact of weather on partial loss of nestlings in the Red-backed Shrike Lanius collurio in eastern Poland. - Acta Ornithologica 41: 15-20. https://doi. org/10.3161/068.041.0107

Golawski, A. (2008): No evidence of weather effect found on the clutch size, eggs sizes and their hatchability in the red-backed shrike Lanius collurio in eastern Poland. - Annales Zoologici Fennici 45: 513-520.

Golawski, A. \& Meissner, W. (2008): The influence of territory characteristics and food supply on the breeding performance of the Red-backed Shrike (Lanius collurio) in an extensively farmed region of eastern Poland. - Ecological Research 23: 347-353. https:// doi.org/10.1007/s11284-007-0383-y

Golawski, A. \& Mitrus, C. (2008): What is more important: nest-site concealment or aggressive behaviour? A case study of the red-backed shrike, Lanius collurio. - Folia Zoologica 57: 403-410.

Golawski, A. \& Mitrus, C. (2014): Nest site characteristics and breeding success of the red-backed shrike Lanius collurio in the agricultural landscape in eastern Poland - advantage of nesting close to buildings. - Ecoscience 21: 168-173. https://doi. org/10.2980/21-2-3653 
Golawski, A. \& Mitrus, C. (2018): Weather conditions influence egg volume repeatability in clutches of the Red-backed Shrike Lanius collurio. - Zoological Studies 57 (2). https://doi.org/10.6620/ZS.2018.57-02

Harris, T. \& Franklin, K. (2000): Shrikes and Bush-Shrikes. - Christoper Helm, London.

Howlett, J. S. \& Stutchbury, B. J. (1996): Nest concealment and predation in Hooded Warblers: experimental removal of nest cover. - Auk113:1-9. https://doi.org/10.2307/4088930

JerzaK, L. (2001): Synurbanization of the Magpie in the Palearctic. Pp. 403-425. In: Marzluff, J. M., Bowman, R. \& Donelly, R. (eds): Avian ecology and conservation in an urbanizing world. - Kluwer, New York. https://doi.org/10.1007/978-1-4615-1531-9_19

Jørgensen, P., Tøttrup, A. P., RAhbek, C. \& Geertsma, M. (2013): Effects of summer weather on reproductive success of the Red-backed Shrike (Lanius collurio). - Bird Study 60: 1-10. https://doi.org/10.1080/00063657.2012.724051

Kuczyński, L. \& Chylarecki, P. (2012): Atlas pospolitych ptaków lęgowych. Rozmieszczenie, wybiórczość siedliskowa, trendy. - GIOŚ, Warszawa, 240 pp.

Kutner, M. H., Nachtsheim, C. J., Neter, J. \& Li, W. (2004): Applied Linear Statistical Models. 5th ed. - McGraw-Hill/Irwin, Chicago, 1396 pp.

Kuzniak, S. \& Tryjanowski, P. (2003): Red-backed Shrike. - Wydawnictwo Klubu Przyrodników, Świebodzin, 128 pp.

Martin, T. E. (1995): Avian life history evolution in relation to nest sites, nest predation, and food. - Ecological Monographs 65: 101-127. https://doi.org/10.2307/2937160

Moreno, J. \& Møller, A. P. (2011): Extreme climatic events in relation to global change and their impact on life histories. - Current Zoology 57: 375-389. https://doi.org/10.1093/ czoolo/57.3.375

Morrison, S. A. \& Bolger, D. T. (2002): Variation in a sparrow's reproductive success with rainfall: food and predator-mediated processes. - Oecologia 133: 315-324. https://doi. org/10.1007/s00442-002-1040-3

Muller, M., Pasinelli, G., Schiegg, K., SpaAr, R. \& Jenni, L. (2005): Ecological and social effects on reproduction and local recruitment in the red-backed shrike. - Oecologia 143: 37-50. https://doi.org/10.1007/s00442-004-1770-5

Newton, I. (1998): Population limitation in birds. - Academic Press, London, 597 pp.

Quinn, G. P. \& Keough, M. J. (2002): Experimental design and data analysis for biologists. Cambridge University Press, Cambridge. https://doi.org/10.1017/CBO9780511806384

RickLefs, R. E. (1969): An analysis of nesting mortality in birds. - Smithsonian Contribution Zoology 9: 1-48. https://doi.org/10.5479/si.00810282.9

Rodriguez, C. \& Bustamante, J. (2003): The effect of weather on lesser kestrel breeding success: can climate change explain historical population declines? - Journal of Animal Ecology 72: 793-810. https://doi.org/10.1046/j.1365-2656.2003.00757.x

Schmidt, K. A. \& Whelan, C. J. (1999): Nest predation on woodland songbirds: when is nest predation density dependent? - Oikos 87: 6-74. https://doi.org/10.2307/3546997

Sherry, T. W., Wilson, S., Hunter, S. \& Holmes, R. T. (2015): Impacts of nest predators and weather on reproductive success and population limitation in a long-distance migratory songbird. - Journal of Avian Biology 46: 559-569. https://doi.org/10.1111/jav.00536

SPSS Inc. (2012): IBM SPSS Statistics for Windows, Version 21.0. - IBM, Corp., Armonk

TAKAGI, M. (2001): Some effects of inclement weather conditions on the survival and condition of bull-headed shrike nestlings. - Ecological Research 16: 55-63.

Tryjanowski, P. \& Golawski, A. (2004): Sex differences in nest defence by the red-backed shrike Lanius collurio: effects of offspring age, brood size, and stage of breeding season. - Journal of Ethology 22: 13-16. https://doi.org/10.1007/s10164-003-0096-9 
Tryjanowski, P., KarG, M. K. \& Karg, J. (2003): Diet composition and prey choice by the red-backed shrike Lanius collurio in western Poland. - Belgian Journal of Zoology 133: 157-162.

Tryjanowski, P. \& KuzNiaK, S. (1999): Effect of research activity on the success of redbacked shrike Lanius collurio nests. - Ornis Fennica 76: 41-43.

Yosef, R. \& Pinshow, B. (2005): Impaling in true shrikes (Laniidae): A behavioral and ontogenic perspective. - Behavioural Processes 69: 363-367. https://doi.org/10.1016/j.beproc.2005.02.023

Vicens, N. \& Bosch, J. (2000): Weather-dependent pollinator activity in an apple orchard, with special reference to Osmia cornuta and Apis mellifera (Hymenoptera: Megachilidae and Apidae). - Environmental Entomology 29: 413-420. https://doi. org/10.1603/0046-225X-29.3.413

Received January 3, 2019, accepted July 5, 2019, published November 22, 2019 
